\title{
VARIATION AND ASSOCIATION ANALYSES ON MORPHOLOGICAL CHARACTERS OF LINSEED (LINUM USITATISSIMUM L.) IN ETHIOPIA
}

\author{
Worku Negash ${ }^{1}$, Zemede Asfaw ${ }^{2}$ and Haileselassie Yibrah $^{3}$ \\ ${ }^{1}$ Department of Applied Biology, Faculty of Applied Science, Gondar University \\ PO Box 920, Gondar, Ethiopia. E-mail: workun59@ethionet.et \\ 2 Department of Biology, Faculty of Science, Addis Ababa University \\ PO Box 1176, Addis Ababa, Ethiopia \\ ${ }^{3}$ Institute of Biodiversity Conservation and Research (IBCR/E) \\ PO Box 30726, Addis Ababa, Ethiopia
}

\begin{abstract}
Morphological studies of linseed (Linum usitatissimum L.) of Ethiopia were undertaken in this study on 56 accessions collected from 10 administrative regions (former regions) classified into seven altitude classes. The seeds were planted during 2001 growing season in Bale-Goro "wereda" using randomized complete block design (RCBD) on three replications with the aim of investigating the morphological diversity in the accessions. Over the entire accession, except seed number per boll, all the characters showed significant variation. However, regional groups of linseed accessions showed insignificant variations only for secondary branches number per plant (SBP), days to flowering (DTF) and days to maturity (DTM) among themselves, and altitudinal groups of linseed accessions only for seed number per boll (SNB) and days to flowering (DTF). The analysis for coefficient of variation and cluster analysis showed that accessions from Gojam and Tigray were less diversified. About $53 \%$ of the total associations showed significant correlation and out of this $71 \%$ of the correlations were with the positive significant correlation coefficients. Cluster analysis indicates that accessions collected from the two extremes of altitude classes have variations for the studied traits. It is only Tigray Region that did not contribute member accession to cluster III, whereas Gondar and Bale regions contribute member accessions to $80 \%$ of clusters. Factor analysis showed that of the total variation $(73.86 \%) 30.04 \%$ and $27.29 \%$ were accounted for by first and second principal components, respectively. The highest Shannon diversity index $(0.322+0.039)$ was recorded for boll size and Shannon diversity index for overall pooled mean was $0.223 \pm 0.063$.
\end{abstract}

\section{Key words/phrases: Cluster/factor analysis, diversity index, linseed accessions, morphological characters, variation/association}

\section{INTRODUCTION}

Linseed (Linum usitatissimum L.) is a member of the family Linaceae containing about 300 species distributed in 25 genera. The genus Linum L. has about 200 species including L. usitatissimum L. (Friedt et al., 1996; Friis, 2000). L. usitatissimum L. is a self-pollinated species with less than $1 \%$ outcrossing although, up to $40 \%$ outcrossing was observed (Seegeler, 1983). The suggested developmental or biological relationships among the different varieties of L. usitatissimum L., is that the procumbent linseeds probably appeared first, and then came the erect types followed by the dual-purpose forms and finally the fiber types (Durrant, 1976). Vavilov (1951) reported that linseed is one of the crops with high diversity in Ethiopia. Moreover, this author showed that Ethiopia, with the Central Asiatic, Near Eastern and Mediterranean diversity centre, is in the place for the origin of linseed.

All the seed, the straw and the chaff of linseed have different use values. The seed is used to extract oil for both cooking and industrial uses (Durrant, 1976; Berhanu Abegaz Gashe and Desta Hamito, 1983; Seegeler, 1983; Dubey, 1990; Friis, 2000). However, its high content in linolenic acid gives it poor quality as edible oil. On the other hand because of its higher linolenic acid linseed seed oil is with high quality as industrial oil (Hiruy Belayneh, 1983; Seegeler, 1983). The oil cake is used as animal feed (Hiruy Belayneh et al., 1981; Shelemew W/Mariam, 1985). The roasted and pounded seed is used to make the component of different traditional food items (Seegeler, 1983; Mulatu Geleta, 2001). In addition to its food and industrial use values, the seed has different medicinal values (Elder and Rathmann, 1962; 
Mulatu Geleta, 2001). The fibers produced from the straw are used to make linen cloth, very strong thread (Hill, 1952; Seegeler, 1983; Friis, 2000), gloves, footwear, netting and sports gear (Durrant, 1976).

Genetic and morphological improvements of crops for drought tolerance, high yield, resistance to insect pests and diseases are the main components of agricultural improvement that could be achieved by utilizing the biological diversity of a given species (Melaku Worede, 1988). Plant genetic resources with highest potential for genetic diversity are represented primarily by landraces, wild relatives of cultivated species and wild/weedy species (Monti, 1992). More specifically in the gene pools genetic resources conservation involves description of variation and association for morphological traits, particularly agro-morphological characteristics of direct interest to users (Bretting and Widerlechner, 1995; Karp et al., 1997).

Ethiopian crops made important contributions in genetic diversity and the need to conserve its genetic stocks have been stressed several times (Harlan, 1969; Endeshaw Bekele, 1983). However, although quantitative estimates of genetic diversity are prerequisite for genetic conservation strategy there was no quantitative estimate on the magnitude of Ethiopian crops genetic diversity until 1983 (Endeshaw Bekele, 1983). Similarly, although it is believed that studies on heritable phenotypic traits, genetic markers and ethnobotanical studies are essential for conservation activities such studies were not carried out on linseed in Ethiopia, except on agronomic characters and very limited ethnobotanical information (Westphal, 1975; Seegeler, 1983; Shelemew W/Mariam, 1985; Hiruy Belayneh et al., 1990; Mulatu Geleta, 2001). A study was, therefore, carried out to fill the gaps in ethnobotanical information as well as in morphological and biochemical data on Ethiopia linseed. This paper is particularly devoted to the study of the diversity, variability and associations of morphological characters of linseed in Ethiopia using gene bank accessions/collections.

\section{DESCRIPTION OF THE EXPERIMENTAL STUDY AREA}

The study was conducted at Bale-Goro at Addis Alem Mana on Institute of Biodiversity Conservation and Research ( $(\mathrm{BCR} / \mathrm{E})$ site, which is located at $07^{\circ} 01^{\prime} \mathrm{N}$ and $040^{\circ} 23^{\prime} \mathrm{E}$, in the Oromia Region. Addis Alem Mana is $482 \mathrm{kms}$ from Addis Ababa via Shashemenee and Robe to Goro town. It is located at 2130masl. The site has two cropgrowing seasons, "Meher" (main rainy season) and "Belg" (small rainy season). Based on the data obtained from National Meteorological Services Agency of Ethiopia (NMSAE), at Meleyu Station (within $3 \mathrm{~km}$ from the study site) the annual average rainfall in the recent nine years, 1993-2001, was $1304.09 \mathrm{~mm}$. The minimum and maximum annual rainfalls were $941.9 \mathrm{~mm}$ for the 1994-year and $1569.8 \mathrm{~mm}$ for the 1997-year, respectively. The monthly minimum rainfall was $18.9 \mathrm{~mm}$ in December and the maximum was $236.3 \mathrm{~mm}$ in October. Monthly average rainfall for the growing season during this study was $100.14 \mathrm{~mm}$. But the rainfall was recorded only for the first three months. Based on the data recorded from Goro station that is about $9 \mathrm{~km}$ from the study site, the monthly average temperature in nine years, 19932001 , was $17.86^{\circ} \mathrm{C}$ whereas the maximum and the minimum temperatures were 28.9 and $4.37^{\circ} \mathrm{C}$ in February and December, respectively.

\section{MATERIALS AND METHODS}

Seed materials were obtained from the IBCR, collected from Shewa, Gondar, Arsi, Bale, Gojam, Wello, Hararghe, Gamogofa, Wellega and Tigray (Table 1). The demarcation of these regions is based on the division for former Administrative Regions and indicated/used by Hedberg and Edwards (1989) in "Flora of Ethiopia Vol. 3". The seed source altitude ranges from 1480 to 3190masl and within this range, taking the maximum possibility to include all the ten regions 56 accessions were selected. Seven altitude classes were made using the formulae:

$\mathrm{K}=1+3.32 \log _{10} \mathrm{n}$ and $\mathrm{i}=$ Range $/ \mathrm{K}($ Agarwal, 1996)

Where $\mathrm{i}=$ class interval width, $\mathrm{K}=$ number of classes and $\mathrm{n}=$ sample size.

The number of cluster was determined using Toit et al. (1986) method:

$$
g=\frac{n}{10} ; \text { where } \mathrm{g}=1,2,3, \mathrm{k} \text { clusters; }
$$

$\mathrm{n}=$ the number of accessions; and

$\mathrm{k}$ usually is the largest integer smaller than $\frac{n}{10}$. 
The experiment was laid out in a randomised complete block design (RCBD) with three replications in a single row. The size of each block, row, and spaces between rows and between blocks were $2.00 \mathrm{~m} \times 22.40 \mathrm{~m}, 0.20 \mathrm{~m} \times 2.00 \mathrm{~m}, 0.20 \mathrm{~m}$ and $2.00 \mathrm{~m}$, respectively. Based on the recommendation from IAR (1985) seeds were planted with $25 \mathrm{~kg} / \mathrm{ha}$ seeding rate over the $0.20 \mathrm{~m} \times 2.00 \mathrm{~m}$ area on October 4, 2001 (corresponding to the "Meher" planting season) on the field that was ploughed twice before planting. Seeds were covered with sufficiently moist soil and days to flowering and maturity were counted starting from the sowing date. There was no application of fertilizers. Weeding was performed twice manually. Following the descriptor for L. usitatissimum L. obtained from IBCR the following morphological characters were recorded: plant height, 1000 -seed weight, primary branches number per plant, secondary branches per plant, boll number per plant, seed number per boll, seed number per plant, seed weight per plant, days to flowering and days to maturity. Seven plants per row and twenty-one plants per accession with a total of $(21$ x 56) 1176 plants were selected using systematic sampling. Each plant was taken at $30 \mathrm{~cm}$ distance on a row: i.e., plants at readings of $0 \mathrm{~cm}, 30 \mathrm{~cm}$, $60 \mathrm{~cm}, 90 \mathrm{~cm}, 120 \mathrm{~cm}, 150 \mathrm{~cm}$, and $180 \mathrm{~cm}$ on the measurement, to evaluate morphological characters both within and between accessions.

Qualitative morphological characters: seed colour with four classes: brown, light brown, beige and yellow; boll size with three classes: large, medium and small; flower colour with four classes: blue, light blue, purple blue and white; and seedling stem colour with two classes: violet and green were scored. Boll size was measured using caliper with $\mathrm{mm}$ unit and the distribution was determined using scattered plot technique. From the scattered plot three patterns were used as distributions for large, medium and small boll sizes. Seeds from the above twenty-one plants from each accession were germinated in the IBCR Biotechnology Laboratory and seedling stem colours were scored from visual observation.

\section{Statistical analysis}

The analysis of mean, correlation, principal components, and cluster analysis by SPSS software (SPSS, 1999), and Chi-square test by MSTATC software (Bricker, 1991) were done. The diversity index on the qualitative morphological characters for the accessions, regional and altitude classes were determined using Shannon diversity index
$(H)$,i.e. $H=-\sum P_{i} * i n P_{i}$; where $P_{i}$ is the proportion of the total number of plants per acccession in the $i^{\text {th }}$ class and $n$ is the number of phenotypic classes for a given trait. Each value of $H$ was divided by its maximum value, $\ln \mathrm{n}$, in order to keep the values between zero and one (denoted as $H^{\prime}$ as used by Yemane Tsehaye and Fassil Kebebew, 2002).

\section{RESULTS AND DISCUSSION}

\section{Coefficient of variation (CV)}

As can be seen in Table 2 the least CV over the entire accession is from $\mathrm{PH}(1.02 \%)$ whereas the highest CV is from SWP (33.03\%) (Gomez and Gomez, 1984) concluded that in field experiments for rice the acceptable $\mathrm{CV}$ for $\mathrm{PH}$ would be about $3 \%$. Hence, although the CV for precision varies greatly with the characters measured and type of plant the above CV for linseed PH showed high precision in the measure of plant height.

Accessions collected from Gojam were with the least CV (Table 3) for about 33.3\% of the quantitative morphological characters. That is accessions from Gojam were less variable. Comparisons among altitudinal classes of accessions fro CVs (Table 4) showed that accessions from altitude class $1 \neq 1700 \mathrm{~m})$ were with the highest CVs for PH, SNB, DTF and DTM. Accessions from altitude class 2 (1701-1950 m) were with the highest CVs for TSW and PBP. In general, the highest CVs for $60 \%$ of the traits were from the accessions collected from altitude classes $1(=1700 \mathrm{~m})$ and 2 (1701-1950 m). This indicates that these linseed accessions tend to be highly variable towards the lowest altitude classes than to the highest altitude classes.

\section{Mean values}

Accessions collected from Arsi showed the highest mean value (Table 3) for PH. Accessions collected from Tigray showed the highest mean values for TSW and SWP. The highest mean values for DTF, DTM and SNB were from accessions collected from Gondar. As Wuletaw Tadesse (1999) reported, DTF and DTM in this region showed similar results in grasspea (Lahyirus sativus L.) populations. Accessions from Gojam showed the highest mean value for SNP but the least mean value TSW. Tigray and Gojam were similar with the results reported by Seegeler (1983) for TSW. The highest mean value for PBP, SBP and BNP were from the accessions collected from Hararghe. 
Table 1. Source regions and altitudes for the sample accessions.

\begin{tabular}{|c|c|c|c|c|}
\hline S. No. & Accession No. & Region/Origin & Locality $^{*}$ & Altitude \\
\hline 1 & 13511 & Arsi & Shirka & 2800 \\
\hline 2 & 13655 & Arsi & Tena & 3190 \\
\hline 3 & 216891 & Arsi & Jeju & 2050 \\
\hline 4 & 231252 & Arsi & Guna & 2330 \\
\hline 5 & 232215 & Arsi & Jeju & 1610 \\
\hline 6 & 236998 & Arsi & Limu and Bilbila & 2565 \\
\hline 7 & 13528 & Bale & Gololcha & 2060 \\
\hline 8 & 13538 & Bale & Gasera & 1520 \\
\hline 9 & 13543 & Bale & Raytu & 2570 \\
\hline 10 & 230025 & Bale & Nensebo & 1830 \\
\hline 11 & 237931 & Bale & Adaba & 2350 \\
\hline 12 & 237934 & Bale & Dinsho & 2800 \\
\hline 13 & 13656 & Gamogofa & Chencha & 2710 \\
\hline 14 & 13657 & Gamogofa & Konso & 2000 \\
\hline 15 & 211477 & Gamogofa & Konso & 1780 \\
\hline 16 & 211478 & Gamogofa & Konso & 1560 \\
\hline 17 & 225801 & Gamogofa & Kemba & 2650 \\
\hline 18 & 13566 & Gojam & Dembecha & 2040 \\
\hline 19 & 13567 & Gojam & Dega Damot & 2810 \\
\hline 20 & 212747 & Gojam & Yilma and Densa & 2340 \\
\hline 21 & 13684 & Gojam & Banja & 2570 \\
\hline 22 & 13685 & Gojam & Dega Damot & 1880 \\
\hline 23 & 10162 & Gondar & Dabat & 2575 \\
\hline 24 & 13522 & Gondar & Fogera & 1840 \\
\hline 25 & 13624 & Gondar & Lay Gayint & 3000 \\
\hline 26 & 13674 & Gondar & Gonder Zuriya & 2390 \\
\hline 27 & 212751 & Gondar & Farta & 2800 \\
\hline 28 & 214249 & Gondar & Debark & 3009 \\
\hline 29 & 223327 & Hararghe & Achar & 2130 \\
\hline 30 & 13637 & Hararghe & Goro guta & 2880 \\
\hline 31 & 208664 & Hararghe & Kunta chele & 2540 \\
\hline 32 & 230817 & Hararghe & Jarso & 2370 \\
\hline 33 & 230821 & Hararghe & Bedeno & 1700 \\
\hline 34 & 230824 & Hararghe & Deder & 2510 \\
\hline 35 & 10100 & Shewa & Addis Alem & 2350 \\
\hline 36 & 13502 & Shewa & Baso and werena & 2810 \\
\hline 37 & 13599 & Shewa & Bereh & 2510 \\
\hline 38 & 212518 & Shewa & Mama Bidir & 3110 \\
\hline 39 & 236846 & Shewa & Baso and werena & 3150 \\
\hline 40 & 236850 & Shewa & Aberhu Neyo & 2800 \\
\hline 41 & 237590 & Shewa & Alaba & 1900 \\
\hline 42 & 219963 & Tigray & Adi Abeyti & 1850 \\
\hline 43 & 223227 & Tigray & Aubah and Saisa & 2570 \\
\hline 44 & 223231 & Tigray & Genta & 2360 \\
\hline 45 & 235167 & Tigray & Tseda Amba & 2060 \\
\hline 46 & 13658 & Wellega & Gobu Seyo & 1890 \\
\hline 47 & 13662 & Wellega & Gidarkiremu & 2090 \\
\hline 48 & 13666 & Wellega & Jima Genet & 2340 \\
\hline 49 & 13753 & Wellega & Dale and Sadi & 1680 \\
\hline 50 & 13622 & Wello & Guba Lafto & 2100 \\
\hline 51 & 13692 & Wello & Were Ilu & 2850 \\
\hline 52 & 13711 & Wello & Legambo & 3070 \\
\hline 53 & 13719 & Wello & Tenta & 3100 \\
\hline 54 & 13725 & Wello & Tehuledere & 2560 \\
\hline 55 & 13734 & Wello & Tehuledere & 2000 \\
\hline 56 & 237491 & Wello & Kalu & 1480 \\
\hline
\end{tabular}

* Local name is given at former "woreda" level.

Table 2. Mean, Std., Min., Max and cv for 56 linseed accessions.

\begin{tabular}{|c|c|c|c|c|c|c|c|c|c|c|}
\hline \multirow{2}{*}{ Parameter } & \multicolumn{10}{|c|}{ Characters* } \\
\hline & $\mathrm{PH}$ & TSW & PBP & SBP & $\mathrm{BNP}$ & SNB & SNP & SWP & DTF & DTM \\
\hline Mean & 51.97 & 4.09 & 4.54 & 19.83 & 60.89 & 6.99 & 423.02 & 1.71 & 81.65 & 127.95 \\
\hline Std. & 9.67 & 0.91 & 1.82 & 4.74 & 18.29 & 0.85 & 126.15 & 0.56 & 8.21 & 11.01 \\
\hline Min. & 27.98 & 2.68 & 2.00 & 10.67 & 29.25 & 4.43 & 203.46 & 0.78 & 61.00 & 98.00 \\
\hline Max. & 75.45 & 6.08 & 9.00 & 30.67 & 96.30 & 8.56 & 728.65 & 3.21 & 94.67 & 153.00 \\
\hline$C V, \%$ & 1.02 & 3.75 & 17.96 & 10.26 & 8.43 & 18.07 & 19.21 & 33.03 & 2.33 & 6.59 \\
\hline
\end{tabular}

${ }^{*} \mathrm{PH}=$ plant height, $\mathrm{TSW}=1000$-seed weight, $\mathrm{PBP}=$ primary branches per plant, $\mathrm{SBP}=$ secondary branches per plant, $\mathrm{BNP}=$ boll number per plant, $\mathrm{SNB}=$ seed number per boll, $\mathrm{SNP}=$ seed number per plant, $\mathrm{SWP}=$ seed weight per plant, $\mathrm{DTF}=\mathrm{days}$ to flowering and DTM = days to maturity. 
Table 3. Mean, Std, Range and CV of quantitative morphological characters by regions.

\begin{tabular}{|c|c|c|c|c|c|c|c|c|c|c|c|c|}
\hline \multirow{2}{*}{ Region } & \multirow{2}{*}{$\begin{array}{l}\text { No of } \\
\text { Acce. }\end{array}$} & \multirow{2}{*}{ Parameter } & \multicolumn{10}{|c|}{ Character } \\
\hline & & & PH & TSW & PBP & SBP & BNP & SNB & SNP & SWP & DTF & DTM \\
\hline \multirow[t]{4}{*}{ Shewa } & \multirow[t]{4}{*}{7} & Mean & 49.45 & 3.80 & 4.90 & 15.19 & 55.38 & 7.49 & 414.52 & 1.56 & 84.62 & 130.86 \\
\hline & & Std. & 5.10 & 0.66 & 2.08 & 4.41 & 16.20 & 0.51 & 27.61 & 0.54 & 6.07 & 9.79 \\
\hline & & Range & 15.33 & 1.53 & 5.66 & 12.33 & 43.52 & 1.44 & 330.32 & 1.59 & 15.95 & 29.05 \\
\hline & & $\mathrm{CV}$ & 10.33 & 17.35 & 42.34 & 29.05 & 29.24 & 6.86 & 30.78 & 34.66 & 7.19 & 7.45 \\
\hline \multirow[t]{4}{*}{ Gondar } & \multirow[t]{4}{*}{6} & Mean & 55.95 & 4.15 & 3.17 & 19.17 & 45.95 & 7.74 & 350.79 & 1.42 & 86.78 & 136.17 \\
\hline & & Std. & 8.27 & 0.97 & 1.11 & 5.45 & 21.90 & 0.51 & 152.17 & 0.55 & 7.80 & 13.31 \\
\hline & & Range & 25.50 & 2.38 & 3.00 & 15.00 & 56.00 & 1.29 & 92.23 & 1.41 & 18.36 & 28.81 \\
\hline & & $\mathrm{CV}$ & 14.78 & 23.42 & 35.01 & 28.42 & 47.67 & 6.59 & 43.38 & 38.50 & 8.96 & 9.70 \\
\hline \multirow[t]{4}{*}{ Arsi } & \multirow[t]{4}{*}{6} & Mean & 57.90 & 4.54 & 4.05 & 20.61 & 65.27 & 6.39 & 407.72 & 1.78 & 84.00 & 128.83 \\
\hline & & Std. & 9.61 & 0.88 & 2.30 & 1.16 & 23.94 & 1.13 & 140.69 & 0.45 & 5.65 & 5.15 \\
\hline & & Range & 22.59 & 2.69 & 6.00 & 3.00 & 56.35 & 2.80 & 393.18 & 1.28 & 14.24 & 12.39 \\
\hline & & $\mathrm{CV}$ & 16.59 & 19.48 & 56.78 & 5.64 & 36.67 & 17.66 & 34.51 & 25.10 & 6.77 & 4.00 \\
\hline \multirow[t]{4}{*}{ Bale } & \multirow[t]{4}{*}{6} & Mean & 56.43 & 4.43 & 5.11 & 17.55 & 59.62 & 7.03 & 417.69 & 1.84 & 74.94 & 119.11 \\
\hline & & Std. & 15.48 & 0.65 & 2.08 & 4.27 & 19.73 & 1.36 & 161.67 & 0.78 & 8.90 & 11.81 \\
\hline & & Range & 46.85 & 1.48 & 5.67 & 10.67 & 57.06 & 3.66 & 436.73 & 2.03 & 21.65 & 30.32 \\
\hline & & $\mathrm{CV}$ & 27.43 & 14.69 & 40.77 & 24.31 & 33.09 & 19.41 & 38.70 & 42.49 & 11.87 & 9.95 \\
\hline \multirow{4}{*}{ Gojam } & \multirow[t]{4}{*}{5} & Mean & 49.74 & 3.40 & 5.29 & 23.40 & 80.54 & 7.53 & 608.20 & 2.10 & 82.47 & 127.27 \\
\hline & & Std. & 7.83 & 0.73 & 1.43 & 2.58 & 11.41 & 0.33 & 95.16 & 0.70 & 4.80 & 2.26 \\
\hline & & Range & 18.74 & 1.88 & 3.45 & 7.00 & 23.19 & 0.74 & 196.05 & 1.70 & 11.98 & 5.88 \\
\hline & & $\mathrm{CV}^{\circ}$ & 15.74 & 21.61 & 26.96 & 11.01 & 14.16 & 4.40 & 18.72 & 33.54 & 5.80 & 1.73 \\
\hline \multirow[t]{4}{*}{ Wello } & \multirow[t]{4}{*}{7} & Mean & 47.53 & 3.71 & 4.90 & 22.90 & 58.14 & 6.87 & 392.25 & 1.48 & 83.48 & 133.00 \\
\hline & & Std. & 9.13 & 0.51 & 1.42 & 3.60 & 18.25 & 0.77 & 100.69 & 0.55 & 11.23 & 16.97 \\
\hline & & Range & 23.34 & 1.14 & 4.66 & 8.00 & 50.64 & 2.30 & 284.37 & 1.61 & 29.40 & 44.55 \\
\hline & & $\mathrm{CV}$ & 19.20 & 13.83 & 28.98 & 16.71 & 31.39 & 11.24 & 25.67 & 37.29 & 13.35 & 11.90 \\
\hline \multirow[t]{4}{*}{ Hararghe } & \multirow[t]{4}{*}{6} & Mean & 51.63 & 3.96 & 6.00 & 24.00 & 66.99 & 6.45 & 426.56 & 1.68 & 86.39 & 131.45 \\
\hline & & Std. & 7.60 & 0.49 & 1.88 & 5.91 & 11.40 & 0.74 & 40.12 & 0.22 & 7.85 & 11.32 \\
\hline & & Range & 20.00 & 1.18 & 5.66 & 14.00 & 32.10 & 1.93 & 109.00 & 0.62 & 22.32 & 32.40 \\
\hline & & $\mathrm{CV}$ & 14.71 & 12.33 & 31.39 & 24.64 & 17.10 & 11.54 & 9.40 & 12.87 & 9.07 & 8.57 \\
\hline \multirow[t]{4}{*}{ Gamogafa } & \multirow[t]{4}{*}{5} & Mean & 49.73 & 3.84 & 3.67 & 17.67 & 63.91 & 6.83 & 433.82 & 1.66 & 80.27 & 125.40 \\
\hline & & Std. & 10.75 & 0.92 & 1.51 & 4.44 & 17.04 & 0.70 & 113.70 & 0.55 & 2.16 & 2.43 \\
\hline & & Range & 23.83 & 2.20 & 3.67 & 11.00 & 41.01 & 1.72 & 281.53 & 1.28 & 4.32 & 5.35 \\
\hline & & $\mathrm{CV}$ & 21.62 & 24.03 & 41.21 & 25.14 & 26.66 & 10.22 & 26.21 & 32.43 & 2.63 & 1.93 \\
\hline \multirow[t]{4}{*}{ Wellega } & \multirow[t]{4}{*}{4} & Mean & 55.36 & 4.10 & 2.83 & 20.17 & 52.87 & 7.02 & 370,18 & 1.55 & 78.91 & 124.83 \\
\hline & & Std. & 13.40 & 1.58 & 0.43 & 3.01 & 10.49 & 0.79 & 71.81 & 0.77 & 2.45 & 3.94 \\
\hline & & Range & 27.24 & 3.15 & 1.00 & 6.33 & 22.83 & 1.81 & 148.72 & 1.79 & 5.16 & 8.59 \\
\hline & & $\mathrm{CV}$ & 24.10 & 38.65 & 15.18 & 14.93 & 19.84 & 11.19 & 19.40 & 49.59 & 3.11 & 3.04 \\
\hline Tigray & 4 & Mean & 45.29 & 5.34 & 4.83 & 17.50 & 63.66 & 6.78 & 433.59 & 2.23 & 68.00 & 115.50 \\
\hline & & Std. & 4.93 & 1.07 & 1.73 & 2.44 & 15.69 & 0.32 & 109.84 & 0.15 & 1.98 & 2.90 \\
\hline & & Range & 10.78 & 2.30 & 3.66 & 5.33 & 32.46 & 0.69 & 245.75 & 0.32 & 4.10 & 7.03 \\
\hline & & $\mathrm{CV}$ & 10.84 & 19.93 & 35.75 & 13.95 & 24.64 & 4.67 & 25.33 & 6.66 & 2.76 & 2.16 \\
\hline
\end{tabular}

For character codes see Table 2.

Accessions collected from altitude class $1(=1700$ m) (Table 4) showed the least mean values for $\mathrm{PH}$, SNP and DTM but the highest mean values for BNP and SNP. This indicates that linseed accessions from low altitudes adapt to mature early using the available short cycle of moisture. Accessions collected from altitude class 7 (= $2951 \mathrm{~m})$ were with the least mean value for TSW, but with maximum SNB. This is in agreement with the finding by Seegeler (1983) that the SNB tends to be inversely correlated with seed size and TSW, and the smallest seeds are found in areas with the high rainfall.
TSW is used as important estimator for the productivity of linseed varieties (Banwal et al., 1971 and Chowdhuti, 1972; both cited in Seegeler, 1983). Similarly, Endeshaw Bekele (1996) reported that mean values are useful to determine variations within and between populations. Therefore, linseed accessions from Gojam and those from the highest altitude are relatively less productive than the accessions from other regions and altitude classes, respectively. Accessions from lowest altitude class took 77 and 44, and from highest altitude class, 89 and 51 days to flowering, and from flowering to maturity, respectively. This could be due to positive effect of longer growing 
season on growth. Maturing in the rainy season decreases the oil content and causes seed decay in linseed (Seegeler, 1983). Therefore, adapting to longer flowering and maturity time in higher altitudes characterized with longer rainy season is advantageous for linseed to flower and mature towards the end of the rainy season.

\section{Analysis of Variance (ANOVA)}

ANOVA on the quantitative morphological characters over the entire accession (Table 5), regional groups and altitude groups (Table 6) were determined. ANOVA over the entire accession (Table 5) showed highly significant differences for the mean values among accessions for all characters, except for SNB. The character that showed significant difference among blocks (replication) was DTF. ANOVA for the mean values of linseed accessions between regions (Table 6) showed significant differences for the mean values of SBP, DTF and DTM. The same analysis between altitude classes showed significant differences for the mean values of SNB and DTF. Therefore, the variation was stronger within a region and an altitude class than between regions or altitude classes. This low variation between regions can be explained in terms of the environmental heterogeneity of each region.

Table 4. Mean, Std, Range and CV of quantitative morphological characters by altitude classes.

\begin{tabular}{|c|c|c|c|c|c|c|c|c|c|c|c|c|}
\hline \multirow{2}{*}{$\begin{array}{l}\text { Altitude } \\
\text { Class in } \mathrm{m}\end{array}$} & \multirow{2}{*}{$\begin{array}{l}\text { No. of } \\
\text { Acce. }\end{array}$} & \multirow{2}{*}{ Parameter } & \multicolumn{10}{|c|}{ Characters code } \\
\hline & & & $\begin{array}{l}\mathrm{PH} \\
\end{array}$ & TSW & PBP & SBP & BNP & SNB & $\overline{\mathrm{SNP}}$ & SWP & DTF & DTM \\
\hline \multirow[t]{4}{*}{$1 .=1700$} & \multirow[t]{4}{*}{6} & Mean & 46.91 & 4.25 & 4.72 & 20.17 & 76.56 & 5.87 & 449.62 & 1.86 & 77.22 & 121.50 \\
\hline & & Std. & 16.22 & 1.05 & 1.62 & 4.49 & 16.01 & 1.12 & 121.69 & 0.52 & 8.41 & 11.97 \\
\hline & & Range & 47.47 & 2.55 & 4.33 & 12.67 & 38.88 & 2.89 & 371.04 & 1.28 & 23.28 & 32.58 \\
\hline & & $\mathrm{CV}$ & 34.58 & 24.62 & 34.41 & 22.25 & 20.19 & 19.10 & 27.06 & 27.72 & 10.93 & 9.84 \\
\hline \multirow[t]{4}{*}{ 2. $1701-1950$} & \multirow[t]{4}{*}{7} & Mean & 50.02 & 3.72 & 4.90 & 19.19 & 63.02 & 7.04 & 447.47 & 1.61 & 78.90 & 123.33 \\
\hline & & Std. & 6.67 & 1.14 & 2.48 & 4.73 & 12.14 & 0.67 & 113.35 & 0.42 & 4.91 & 4.83 \\
\hline & & Range & 20.14 & 3.34 & 7.00 & 11.33 & 33.53 & 1.54 & 302.11 & 1.08 & 14.43 & 12.39 \\
\hline & & $\mathrm{CV}$ & 13.34 & 30.66 & 50.52 & 24.66 & 19.27 & 9.56 & 25.33 & 25.82 & 6.15 & 3.89 \\
\hline \multirow[t]{4}{*}{ 3. $1951-2200$} & \multirow[t]{4}{*}{9} & Mean & 51.51 & 4.09 & 4.52 & 21.00 & 62.81 & 6.81 & 424.00 & 1.74 & 76.67 & 122.78 \\
\hline & & Std. & 12.79 & 1.02 & 2.04 & 4.45 & 16.40 & 0.59 & 96.05 & 0.59 & 7.20 & 8.62 \\
\hline & & Range & 39.57 & 2.89 & 5.66 & 15.00 & 54.21 & 1.89 & 290.29 & 1.81 & 18.91 & 28.17 \\
\hline & & $\mathrm{CV}$ & 24.83 & 24.94 & 45.13 & 21.19 & 26.09 & 8.66 & 22.65 & 33.92 & 9.27 & 5.63 \\
\hline \multirow[t]{4}{*}{ 4. $2201-2450$} & \multirow[t]{4}{*}{8} & Mean & 55.13 & 4.64 & 4.64 & 18.54 & 51.54 & 7.32 & 375.79 & 1.70 & 83.62 & 131.17 \\
\hline & & Std. & 7.17 & 0.90 & 1.75 & 5.04 & 19.87 & 0.70 & 156.12 & 0.55 & 8.97 & 11.83 \\
\hline & & Range & 19.00 & 2.72 & 5.12 & 15.00 & 63.13 & 2.10 & 506.03 & 1.47 & 25.30 & 34.41 \\
\hline & & $\mathrm{CV}^{\circ}$ & 13.00 & 19.49 & 43.26 & 27.16 & 38.55 & 9.67 & 41.54 & 32.54 & 10.74 & 9.00 \\
\hline \multirow[t]{4}{*}{ 5. $2451-2700$} & \multirow[t]{4}{*}{10} & Mean & 49.68 & 4.42 & 4.73 & 21.87 & 64.81 & 6.86 & 448.86 & 1.99 & 80.70 & 126.60 \\
\hline & & Std. & 8.11 & 0.62 & 1.51 & 4.82 & 20.84 & 0.82 & 163.40 & 0.77 & 9.11 & 9.62 \\
\hline & & Range & 23.19 & 1.86 & 4.67 & 15.67 & 58.50 & 2.58 & 490.38 & 2.22 & 28.20 & 35.24 \\
\hline & & $\mathrm{CV}$ & 16.33 & 13.91 & 31.80 & 22.03 & 32.16 & 11.98 & 36.40 & 38.94 & 1.12 & 7.63 \\
\hline \multirow[t]{4}{*}{ 6. 2701-2950 } & \multirow[t]{4}{*}{9} & Mean & 56.72 & 4.00 & 3.89 & 19.59 & 55.76 & 7.48 & 406.25 & 1.62 & 85.33 & 130.07 \\
\hline & & Std. & 8.86 & 0.64 & 1.40 & 4.98 & 17.04 & 0.76 & 102.76 & 0.49 & 6.14 & 9.83 \\
\hline & & Range & 23.55 & 1.90 & 3.34 & 14.33 & 49.22 & 2.61 & 312.17 & 1.60 & 16.67 & 29.25 \\
\hline & & $\mathrm{CV}$ & 15.61 & 15.86 & 36.09 & 25.40 & 30.56 & 10.17 & 25.29 & 30.05 & 7.19 & 7.53 \\
\hline \multirow[t]{4}{*}{ 7. $=2951$} & \multirow[t]{4}{*}{7} & Mean & 52.40 & 3.32 & 5.14 & 17.57 & 54.57 & 7.58 & 413.16 & 1.34 & 89.00 & 140.24 \\
\hline & & Std. & 5.12 & 0.63 & 2.38 & 4.99 & 19.04 & 0.39 & 140.75 & 0.39 & 6.42 & 11.49 \\
\hline & & Range & 14.67 & 1.91 & 5.66 & 12.33 & 48.15 & 1.07 & 328.41 & 1.06 & 16.03 & 24.64 \\
\hline & & $\mathrm{CV}$ & 9.76 & 18.94 & 46.36 & 28.37 & 34.90 & 5.20 & 34.07 & 29.08 & 7.21 & 8.09 \\
\hline
\end{tabular}

For character codes see Table 2.

Table 5. Mean squares for quantitative morphological traits of 56 linseed accessions.

\begin{tabular}{|c|c|c|c|c|c|c|c|c|c|c|}
\hline \multirow{2}{*}{$\begin{array}{l}\text { Source of } \\
\text { variation }\end{array}$} & \multicolumn{10}{|c|}{ Character } \\
\hline & $\mathrm{PH}$ & TSW & РBP & SBP & BNP & SNB & SNP & SWP & DTF & DTM \\
\hline $\begin{array}{l}\text { Replication } \\
(\mathrm{df}=2)\end{array}$ & 0.79 & 0.01 & 1.30 & 9.24 & 29.77 & 1.15 & 3434.53 & 0.09 & $110.97^{* *}$ & 138.34 \\
\hline $\begin{array}{l}\text { Accession } \\
(\mathrm{df}=165)\end{array}$ & $280.8^{* *}$ & $2.47^{* *}$ & $10.06^{* *}$ & $67.31^{* *}$ & $1003.48^{* *}$ & 1.93 & $47746.53^{* *}$ & $0.95^{* *}$ & $209.93^{* *}$ & $462.85^{* *}$ \\
\hline $\begin{array}{l}\text { Error } \\
(\mathrm{df}=167)\end{array}$ & 0.28 & 0.02 & 0.66 & 4.14 & 26.34 & 1.60 & 6604.85 & 0.13 & 3.63 & 70.94 \\
\hline
\end{tabular}

** stands for 0.01 and * for 0.05 level of significances; $\mathrm{df}=$ degree of freedom; for Character codes see Table 2. 
Table 6. Mean squares for quantitative morphological traits of linseed within and between regions and altitude groups.

\begin{tabular}{ccccc}
\hline \multirow{2}{*}{ Characters } & \multicolumn{2}{c}{ ANOVA by regions } & \multicolumn{2}{c}{ ANOVAby altitude classes } \\
\cline { 2 - 5 } & \multicolumn{2}{c}{ Source of variation } & \multicolumn{2}{c}{ Source of variation } \\
\cline { 2 - 5 } & Between groups & Within a group & Between groups & Within a group \\
\hline PH & 98.07 & 92.71 & 86.40 & 94.46 \\
TSW & 1.40 & 0.71 & 1.48 & 0.74 \\
PBP & 5.33 & 2.98 & 1.62 & 3.47 \\
SBP & $51.98^{* *}$ & 16.66 & 17.81 & 23.01 \\
BNP & 468.50 & 308.30 & 484.89 & 316.10 \\
SNB & 1.19 & 0.64 & $2.22^{* *}$ & 0.55 \\
SNP & 24860.58 & 14165.25 & 6029.24 & 17125.94 \\
SWP & 0.346 & 0.312 & 0.345 & 0.314 \\
DTF & $157.22^{* *}$ & 49.40 & $155.73^{*}$ & 56.18 \\
DTM & $365.69^{* *}$ & 112.92 & 177.96 & 139.14 \\
Degree of freedom $(\mathrm{df})$ & 9 & 46 & 6 & 49 \\
\hline
\end{tabular}

For Character codes see Table 2.

\section{Correlation}

As indicated in Table 7 PH, SNB, DTF and DTM were with positive significant correlations with each other. TSW was with significant negative associations with PBP, DTF and DTM, but with significant positive associations with SWP. Shelemew W/Mariam (1985) reported similar results for the association between TSW and PH, PBP, SBP and SNB. Lin and Nelson (1988) working on determinate soya bean also showed that delayed flowering increased plant height.

Positive correlations could result from the presences of common genetic elements or microenvironments (or both) that control the characters to the same direction. Positive significant correlation due to effect of genes can be the result of the presence of strong coupling linkage between their genes or the characters may be the result of pleiotropic genes that control these characters in the same direction (Kearsey and Pooni, 1996).

The negative significant associations for TSW with PBP, DTF and DTM could be explained in that the available resources were used up in the production of profuse vegetative growth for longer time at the expense of material production that should be stored in the seeds. An alternative explanation is that different genes or pleiotropic genes that have dominance on the characters may control the characters in different directions (Kearsey and Pooni, 1996). Therefore, desiring to develop a cultivar having higher TSW simultaneously with these traits could be achieved in difficulty.

\section{Cluster analysis}

After standardizing each value measured for the quantitative characters into $z$ score, using the average linkage between groups method, cluster analysis for the entire accessions was made (Fig. 1). The entire accessions were divided into two general groups, $G_{A}$ and $G_{B}$ i.e. $G_{A}$ with 51 and 5 member of accessions, respectively. The marker morphological characters that grouped the entire accession into the first two groups are TSW, DTF and DTM. Clusters under $\mathrm{G}_{\mathrm{A}}$ (I, II, and III) are with lower mean value for TSW but higher values for DTF and DTM and the reverse is true for clusters under G (IV and V). Accession 13538, collected from Bale at altitude $1520 \mathrm{~m}$, formed one independent cluster, cluster $\mathrm{V}$. The accession was with the least mean values for PH, SNB, DTF and DTM, and the seeds were twin-seeded. The average seed weight (ISW $=5.08 \mathrm{~g}$ ) of these twinseeded seeds was above the average weight (TSW $=4.09 \mathrm{~g}$ ) of the seeds of the whole sample accessions. Therefore, Cluster analysis revealed that accession 13538 would have specific position in the classification of these linseed accessions.

Except Tigray, all the regions contributed member accessions to cluster III, a cluster consisting about $50 \%$ of the total sample accessions. Gondar, Bale and Arsi regions contributed member accessions to three and four clusters whereas the rest regions contributed only to two clusters. Sixty percent of $G_{B}$ member accessions were from Tigray and $75 \%$ of the accessions from this region remained being the member of one cluster, cluster IV. This may hint at the presence of genetic similarity among the accessions and that they are different from the other regional groups of accessions. 
Table 7. Correlations between the quantitative morphological characters.

\begin{tabular}{|c|c|c|c|c|c|c|c|c|c|c|}
\hline Char. & $\mathrm{PH}$ & TSW & PBP & SBP & BNP & SNB & SNP & SWP & DTF & DTM \\
\hline PH & -ב-- & & & & & & & & & \\
\hline TSW & 0.261 & ------ & & & & & & & & \\
\hline РВР & -0.175 & $-0.301^{*}$ & ------ & & & & & & & \\
\hline SBP & 0.029 & -0.008 & $0.407^{* *}$ & --_--- & & & & & & \\
\hline BNP & -0.218 & -0.100 & $0.387^{* *}$ & $0.408^{* *}$ & ----- & & & & & \\
\hline SNB & $0.404^{* *}$ & -0.243 & -0.050 & -0.119 & $-0.297^{*}$ & ----- & & & & \\
\hline SNP & -0.082 & -0.208 & $0.387^{* *}$ & $0.372^{* *}$ & $0.905^{* *}$ & 0.117 & ------ & & & \\
\hline SWP & 0.134 & $0.474^{* *}$ & 0.119 & $0.313^{*}$ & $0.736^{* *}$ & -0.052 & $0.747^{* *}$ & ------ & & \\
\hline DTF & $0.362^{* *}$ & $-0.353^{* *}$ & 0.000 & -0.023 & $-0.300^{*}$ & $0.403^{\text {** }}$ & -0.167 & $-0.369^{* *}$ & ----- & \\
\hline DTM & $0.329^{*}$ & $-0.374^{* *}$ & -0.003 & -0.056 & -0.272 & $0.358^{* *}$ & -0.149 & $-0.344^{* *}$ & $0.866^{* *}$ & ----- \\
\hline
\end{tabular}

** $=$ Correlation is significant at the 0.01 level and * at the 0.05 level. For Character codes see Table 2.

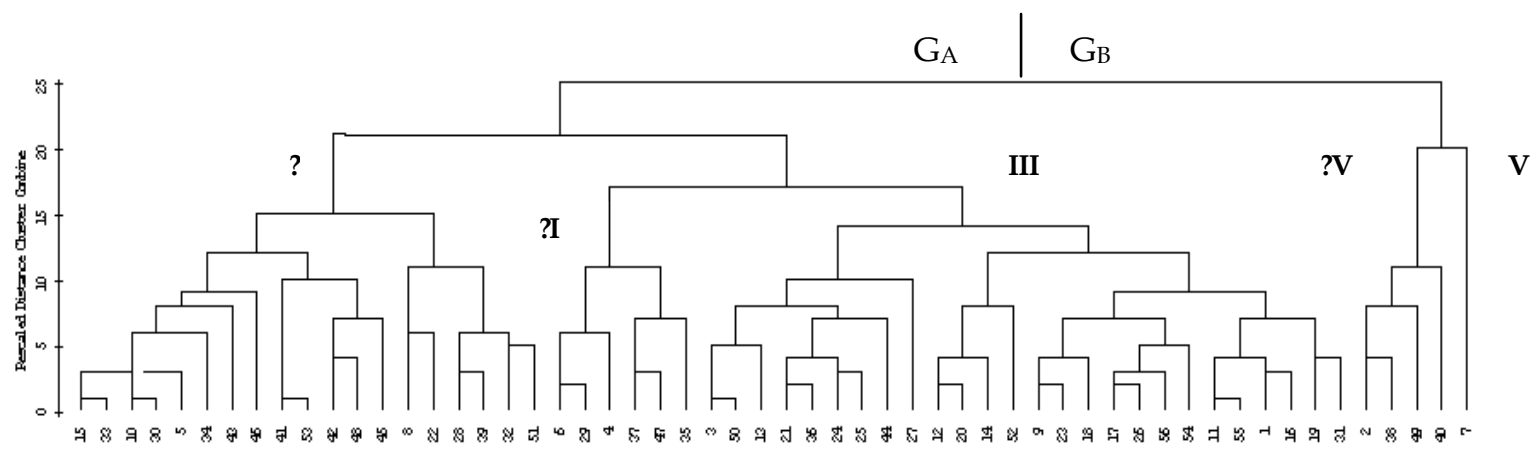

Accessions

Fig. 1. A dendrogram from quantitative morphological characters using average linkage between groups for 56 accessions.

All the accessions from altitude classes 6 (2701$2950 \mathrm{~m})$ and $7(=2951 \mathrm{~m})$ moved together into one group, $\mathrm{G}_{\mathrm{A}}$, up to the final stage of clustering. Moreover, $71.4 \%$ of the accessions from altitude class $7(=2951 \mathrm{~m})$ were grouped under one cluster, cluster III. Similarly $66.57 \%$ of the accessions from the other extreme altitude class, class $1(=1700 \mathrm{~m})$ were grouped into one cluster, cluster I. But the range for the highest percentage of accessions number contributed to one cluster by each of the rest altitude classes was from $44.44 \%$ to $62.5 \%$. This shows that accessions from the two extreme altitude classes may have great genetic differences. Franco et al. (1997) reported that cluster analysis groups genetically similar populations in to one core subset.

\section{Principal component (PC) analysis}

As indicated in Table 8, the first three PCs accounted for $73.86 \%$ of the total variation. Chatfield (1995) explained that factor analysis is often used in data reduction to identify a small number of factors that explain most of the variance observed in a much larger number of variables and can also aid in the selection of better genotypes.
In Table 9, under PC 1 the highest weight or load for the common factor is from SNP, which accounts for about $19.32 \%$ of the variation accounted for by PC 1. Under PC 2 the highest load is from DTM, which accounts for about $19.95 \%$ of the variation accounted for by PC 2 . The first three largest factors under PC 1 were the productivity factor. The first two largest factors under PC 2 were the phonological factors. These phonological factors, DTM and DTF, are the first two agronomic characters used as the main criteria for evaluation to release and register a variety (Abbas, 2001).

\section{Linseed diversity}

The morphological variation in Ethiopian linseed landraces was estimated (Table 10) by the Shannon-Weaver Diversity Index for both regional and altitudinal groups based on qualitative characters. Brown, light brown, beige and yellow; large, medium and small; blue, light blue, purple blue and white; and violent and light green classes of traits were recorded for seed colour, boll size, flower colour and seedling stem colour, respectively. 
Table 8. Eigenvalues for the first three PCs and the distribution of the cumulative variance accounted for by these PCs on different characters among the three PCs.

\begin{tabular}{|c|c|c|c|c|c|c|c|c|c|}
\hline \multicolumn{4}{|c|}{ Initial Eigenvalues } & \multicolumn{3}{|c|}{$\begin{array}{l}\text { Extraction Sum of Squared } \\
\text { Loadings }\end{array}$} & \multicolumn{3}{|c|}{$\begin{array}{l}\text { Rotation Sums of Squared } \\
\text { Loadings }\end{array}$} \\
\hline$\overline{P C}$ & Total & $\%$ of Varia. & Cum \% & Total & $\%$ of Varia. & Cum $\%$ & Total & $\%$ of Varia. & Cum \% \\
\hline 1 & 3.49 & 34.94 & 34.49 & 3.49 & 34.94 & 34.49 & 3.00 & 30.04 & 30.04 \\
\hline 2 & 2.24 & 22.39 & 57.33 & 2.24 & 22.39 & 57.33 & 2.73 & 27.29 & 57.33 \\
\hline 3 & 1.65 & 16.54 & 73.86 & 1.65 & 16.54 & 73.86 & 1.77 & 17.73 & 73.86 \\
\hline
\end{tabular}

Table 9. The first two PCs extracted from the principal component matrix after Varimax rotation for 10 quantitative characters of 56 linseed accessions.

\begin{tabular}{lllllllllll}
\hline Variable & SNP & BNP & SWP & SBP & PBP & DTM & DTF & SNB & PH & TSW \\
\hline PC 1 & 0.942 & 0.898 & 0.787 & 0.599 & 0.533 & -0.183 & -0.153 & 0.020 & 0.012 & -0.750 \\
PC 2 & -0.121 & -0.285 & -0.145 & 0.198 & -0.208 & 0.858 & 0.854 & 0.717 & 0.673 & -0.242 \\
\hline
\end{tabular}

* $\mathrm{PH}=$ plant height, $\mathrm{TSW}=1000$-seed weight, $\mathrm{PBP}=$ primary branches per plant, $\mathrm{SBP}=$ secondary bra nches per plant, $\mathrm{BNP}=$ boll number per plant, $\mathrm{SNB}=$ seed number per boll, $\mathrm{SNP}=$ seed number per plant, $\mathrm{SWP}=$ seed weight per plant, $\mathrm{DTF}=$ days to flowering and DTM = days to maturity.

Table 10. Shannon's mean diversity index values by region, altitude class and entire accession.

\begin{tabular}{|c|c|c|c|c|c|c|}
\hline \multicolumn{7}{|c|}{ A. By region } \\
\hline Region & $\begin{array}{l}\text { No. of } \\
\text { Acce. }\end{array}$ & $\begin{array}{l}\text { Seed } \\
\text { colour }\end{array}$ & $\begin{array}{l}\text { Boll } \\
\text { size }\end{array}$ & $\begin{array}{l}\text { Flower } \\
\text { colour }\end{array}$ & $\begin{array}{c}\text { Seedling stem } \\
\text { colour }\end{array}$ & Mean \\
\hline Shewa & 7 & $0.24 \pm 0.08$ & $0.47 \pm 0.13$ & $0.28 \pm 0.68$ & $0.14 \pm 0.10$ & $0.28 \pm 0.07$ \\
\hline Gondar & 6 & $0.16 \pm 0.09$ & $0.24 \pm 0.17$ & $0.16 \pm 0.40$ & $0.12 \pm 0.12$ & $0.17 \pm 0.03$ \\
\hline Arsi & 6 & $0.27 \pm 0.07$ & $0.40 \pm 0.09$ & $0.37 \pm 0.83$ & $0.13 \pm 0.08$ & $0.29 \pm 0.06$ \\
\hline Bale & 6 & $0.36 \pm 0.11$ & $0.35 \pm 0.13$ & $0.13 \pm 0.49$ & $0.05 \pm 0.05$ & $0.22 \pm 0.08$ \\
\hline Gojam & 5 & $0.12 \pm 0.07$ & $0.04 \pm 0.04$ & $0.17 \pm 0.55$ & $0.09 \pm 0.09$ & $0.11 \pm 0.03$ \\
\hline Wello & 7 & $0.28 \pm 0.09$ & $0.27 \pm 0.10$ & $0.30 \pm 0.63$ & $0.21 \pm 0.14$ & $0.27 \pm 0.02$ \\
\hline Hararghe & 6 & $0.24 \pm 0.08$ & $0.24 \pm 0.08$ & $0.26 \pm 0.80$ & $0.16 \pm 0.10$ & $0.22 \pm 0.02$ \\
\hline Gamogofa & 5 & $0.17 \pm 0.10$ & $0.51 \pm 0.06$ & $0.29 \pm 0.56$ & $0.00 \pm 0.00$ & $0.24 \pm 0.12$ \\
\hline Wellega & 4 & $0.22 \pm 0.08$ & $0.24 \pm 0.13$ & $0.09 \pm 0.50$ & $0.00 \pm 0.00$ & $0.14 \pm 0.06$ \\
\hline Tigray & 4 & $0.46 \pm 0.09$ & $0.46 \pm 0.15$ & $0.06 \pm 0.49$ & $0.00 \pm 0.00$ & $0.24 \pm 0.13$ \\
\hline \multicolumn{7}{|c|}{ B. By altitude class } \\
\hline $\begin{array}{l}\text { Altitude } \\
\text { class }\end{array}$ & $\begin{array}{l}\text { No. of } \\
\text { Acce. }\end{array}$ & $\begin{array}{l}\text { Seed } \\
\text { Colour }\end{array}$ & $\begin{array}{l}\text { Boll } \\
\text { Size }\end{array}$ & $\begin{array}{l}\text { Flower } \\
\text { colour }\end{array}$ & $\begin{array}{c}\text { Seedling stem } \\
\text { colour }\end{array}$ & Mean \\
\hline$=1700$ & 6 & $0.23 \pm 0.07$ & $0.14 \pm 0.08$ & $0.43 \pm 0.04$ & $0.22 \pm 0.11$ & $0.26 \pm 0.06$ \\
\hline 1701-1950 & 7 & $0.19 \pm 0.08$ & $0.20 \pm 0.10$ & $0.09 \pm 0.07$ & $0.04 \pm 0.04$ & $0.20 \pm 0.08$ \\
\hline $1951-2200$ & 9 & $0.19 \pm 0.06$ & $0.43 \pm 0.08$ & $0.34 \pm 0.12$ & $0.00 \pm 0.00$ & $0.24 \pm 0.09$ \\
\hline $2251-2450$ & 8 & $0.29 \pm 0.07$ & $0.18 \pm 0.07$ & $0.31 \pm 0.10$ & $0.15 \pm 0.10$ & $0.23 \pm 0.04$ \\
\hline $2451-2700$ & 10 & $0.24 \pm 0.06$ & $0.31 \pm 0.09$ & $0.14 \pm 0.06$ & $0.09 \pm 0.06$ & $0.20 \pm 0.05$ \\
\hline $2701-2950$ & 9 & $0.20 \pm 0.07$ & $0.53 \pm 0.12$ & $0.22 \pm 0.08$ & $0.16 \pm 0.10$ & $0.28 \pm 0.09$ \\
\hline$=2951$ & 7 & $0.31 \pm 0.08$ & $0.24 \pm 0.11$ & $0.06 \pm 0.07$ & $0.04 \pm 0.04$ & $0.16 \pm 0.07$ \\
\hline Overall & 56 & $0.24+0.03$ & $0.30 \pm 0.04$ & $0.22+0.03$ & $0.10 \pm 0.03$ & $0.22+0.06$ \\
\hline
\end{tabular}

Boll size shows the highest $(0.32 \pm 0.03)$ mean diversity index value whereas seedling stem colour shows the lowest $(0.10 \pm 0.03)$ mean diversity index value. The first three regions with the highest mean diversity indices pooled over traits are Arsi $(0.29 \pm 0.06)$, Shewa $(0.28 \pm 0.07)$ and Wello $(0.27 \pm 0.02)$. On the other hand Gojam $(0.11 \pm 0.03)$,
Wellega $(0.12 \pm 0.06)$ and Gondar $0.17 \pm 0.03)$ were with the lowest pooled mean diversity indices. Accessions collected from Gamogofa, Wellega and Tigray were monomorphic $(0.00 \pm 0.00)$ for seedling stem colour. Altitude class 6 2701-2950m) was with the highest $(0.28 \pm 0.09)$ mean diversity index pooled over traits, whereas altitude class 7 (= 
$2951 \mathrm{~m})$ was with the least $(0.16 \pm 0.07)$ mean diversity index pooled over traits. Accessions collected from altitude classes 2 (1701-1950m) and 7 (= 2951m) were almost monomorphic for flower colour. Analysis of variance for the mean diversity indices showed that there is no significant difference between the regional groups of linseed accessions for all the characters. As it can be seen from Table 11, the only character that shows significant variation between altitudinal groups at $5 \%$ level of significance was flower colour. The Chi-square tests (Table 12) showed that the variation is random within each region and altitude class than between regions and between altitude classes.

When multiple comparisons for the variables are made between regional groups of linseed accessions using LSD (least significant difference), accessions from Tigray showed significant differences with accession collected from Gondar, Gojam and Gamogofa for seed colour. Accessions from Gojam showed significant difference with accessions collected from Shewa, Arsi, Gamogofa and Tigray for boll size at the 0.05 level of significance.

When multiple comparisons for the variables are made between altitude groups of linseed accessions using LSD altitude class 6 (2701-2950) showed significant differences with altitude classes
1 (=1700), 2 (1701-1950), 4 (2201-2450) and 7 $(=2951)$ for boll size. Altitude class $1(=1700)$ with altitude classes 2 (1701-1950), 5 (2451-2700) and 7 (=2951); altitude class 2 (1701-1950) with altitude classes 1(=1700) and 3 (1951-2200); altitude class 5 (2451-2700) with altitude class 1(=1700); altitude class $7(=2951)$ with altitude classes $1(=1700), 3$ (1951-2200) and 4 (2201-2450) showed significant differences for flower colour at the 0.05 level of significance. This confirms that most altitude groups of linseed accessions are significantly variable for flower colour.

However, the mean diversity indices for the accessions from the South and Southwest are relatively higher than the mean diversity indices for those from the northern part of Ethiopia. Similar trends for finger millet (Eleusine coracana L. Gaertn. subsp. coracana [Poeceae]) (Yemane Tsehaye and Fassil Kebebew, 2002) and for "Teff" (Eragrostis tef (Zucc. (Trotter)) (Endeshaw Bekele, 1996) were reported. According to Endeshaw Bekele (1996) the migration effect of the people from the central and northern part of Ethiopia into the South carrying their seed stocks with them, and the presence of diversified and wetter habitats in the South could be the possible reasons for the occurrence of high mean diversity indices from the South. Indeed, the longer a species has been in an area, the greater the time it had to accumulate genetic variability.

Table 11. Mean squares for qualitative morphological traits of linseed within and between regions and altitude groups.

\begin{tabular}{|c|c|c|c|c|}
\hline \multirow{3}{*}{ Characters } & \multicolumn{2}{|c|}{ ANOVA by regions } & \multicolumn{2}{|c|}{ ANOVA by altitude classes } \\
\hline & \multicolumn{2}{|c|}{ Source of variation } & \multicolumn{2}{|c|}{ Source of variation } \\
\hline & Between groups & Within a group & Between groups & Within a group \\
\hline Seed colour & 0.027 & 0.043 & 0.017 & 0.043 \\
\hline Boll size & 0.084 & 0.084 & 0.165 & 0.074 \\
\hline Flower colour & 0.046 & 0.068 & $0.132^{*}$ & 0.056 \\
\hline Seedling stem colour & 0.029 & 0.052 & 0.064 & 0.052 \\
\hline Degree of freedom (df) & 9 & 46 & 6 & 49 \\
\hline
\end{tabular}

Table 12. The Chi-Square test for qualitative morphological traits among linseed accessions.

\begin{tabular}{ccccc}
\hline & Seed colour & Boll size & Flower colour & Seedling stem colour \\
\hline Chi-Square & $75.750^{\star *}$ & $131.607^{* *}$ & $162.571^{\star *}$ & $164.286^{* *}$ \\
df & 16 & 16 & 14 & 5 \\
\hline
\end{tabular}




\section{CONCLUSION}

The Investigation on quantitative characters variability and association for 56 linseed accessions collected from different administrative regions (former) and altitude classes in Ethiopia indicated the presence of high diversity in Bale and Gondar regions and low diversity in Gojam region. Accessions from Gojam were also with the least pooled mean diversity index for qualitative characters. In general linseeds from Gojam, Wellega and Tigray relatively have low diversity. Both cluster and Shannon-Weaver Diversity Index analyses showed that accessions collected altitude class $7(=2951 \mathrm{~m})$ are with the least variation. Based on factor analysis, which effectively selected out important traits from the whole characters, the first two agronomic characters used as the main criteria for evaluation to release and register a variety are found to be the factors under PC 2 as phonological factors. Germplasm collection programmes for $e x$ situ conservation and selecting sites for in situ conservation for linseed priority attention needs to be given to the Bale and Gondar regions. In addition to the regions with high mean diversity indices, the North and North-western parts of Ethiopia need prior attention for germplasm collection programme.

\section{ACKNOWLEDGEMENTS}

The first author would like to acknowledge the School of Graduate Studies of Addis Ababa University for its financial support, and the Institute of Biodiversity Conservation and Research (IBCR), Ethiopia for providing the seed sample and laboratory for the research work that led to the preparation of this paper.

\section{REFERENCE}

1. Abbas, A.S. (2001). The seed industry in Iraq: Focus on seed programmes (15): Iraq January 2001.

2. Agarwal, B.L. (1996). Basic Statistics, $3^{\text {rd }}$ ed. New Age International (P) Limited, New Delhi, 713 pp.

3. Berhanu Abegaz Gashe and Desta Hamito (1983). Preliminary survey of oil-bearing plants in some regions of Ethiopia. Ethiopian J. Agr. Sci. 2:89-96.

4. Bretting, P.K. and Widerlechner, M.P. (1995). Genetic markers and plant genetic resource management. In: Plant Breeding Reviews, Vol.13, pp.11-86, (Janick, J., ed.) John Willy and Sons.
5. Bricker, Ms.B. (1991). MSTATC: A Computer Software Programme. Michigan State University, USA.

6. Chatfield, C. (1995). Problem Solving: A Statistician's Guide, $2^{\text {nd }}$ ed. Chapman and Hall, London, 325 pp.

7. Dubey, R.N. (1990). Cultivation and Varietal Improvement of Linseed in India. In: Oil Crops, 4-17 January 1989, pp. 180-185, (Omran, A., ed.) Proceedings of the three meetings held at Pantnagar and Hydrabad, India.

8. Durrant, A. (1976). Flax and linseed: Linum usitatissimum L. (Linaceae). In: Evolution of Crop Plants, pp. 190-193, (Simmonds, N.W., ed.) Longman, London and New York.

9. Elder, A.L. and Rathmann, D.M. (1962). Seed Oil in Human Nutrition. Econ. Bot. 16:196-205.

10. Endeshaw Bekele (1983). Some measures of gene diversity analysis on land race populations of Ethiopian barley. Hereditas 98:127-143.

11. Endeshaw Bekele (1996). Morphological analysis of Eragrostis teff: Detection for regional patterns of variation. SINET: Ethiop. J. Sci. 19:117-140.

12. Franco, J., Crossa, J., Villasenor, J., Tab, S. and Eberhart, S.A. (1997). Classifying Mexican Maize populations using hierarchical and density search methods. Crop Sci. 37:972-980.

13. Friedt, W., Bickert, C. and Schaub, H. (1996). In vitro breeding of high linolenic, doubled haploid lines of Linseed (Linum usitatissimum L.) via androgenesis. Plant Breeding 114:322-326.

14. Friis, Ib. (2000). Linaceae: Linum. In: Flora of Ethiopia and Eritrea: Manonoliaceae to Flacourtiaceae, Vol. 2, pp. 352-357, (Edwards, S., Mesfin Tadesse, Sebssibe Demissew and Hedberg, I., eds). The National Herbarium, Biology Department, Science Faculty, Addis Ababa, Ethiopia.

15. Gomez, K.A. and Gomez, A.A. (1984). Statistical Procedures for Agricultural Research, 2nd ed. John Wiley and Sons, New York, Chishester, 680 pp.

16. Harlan, J.R. (1969). Ethiopia: A Centre of Diversity. Econ. Bot. 23:309-314.

17. Hedberg, I. and Edwards, S. (1989). Map of Ethiopia showing the regions used to describe the distribution of plants in the flora. In: Flora of Ethiopia: Pittosporaceae to Araliaceae, Vol.3, second cover page. The National Herbarium, Biology Department, Science Faculty, Addis Ababa, Ethiopia and the Department of Systematic Botany, Uppsala University, Sweden.

18. Hill, A.F. (1952). Economic Botany: A textbook of Useful Plants and Plant Products, $2^{\text {nd }}$ ed. McGRAWHALL Book Company, Inc. New York, 560 pp.

19. Hiruy Belayneh (1983). Highland oil crops production and research in Ethiopia. In: Oil Crops: proceedings of a workshop, September 3-8, 
1983, pp. 63-71, (Riley, K. W., ed.). Cairo, Egypt.

20. Hiruy Belayneh, Kiflu Bedane and Nigatu Taddesse (1981). Research on Oil and Industrial Crops in Ethiopia. Summary of Research Activities at Sheno Substation, 1977/78-1979/80. IAR, Addis Ababa, Ethiopia, pp. 1-43.

21. Hiruy Belayneh, Nigussie Alemayehu and Getinet Alemawu (1990). Progress in Linseed OnStation and On-Farm Research in Ethiopia. In: Oil Crops: Proceedings of the Three Meeting Held at Pantnagar and Hydrabad, 4-17 January 1989, pp. 220-227, (Omran, A., ed.) India.

22. IAR (1985). Ethiopian Highland Oil Crops Improvement Team Progress Report No. 4. Institute of Agricultural Research. Addis Ababa, Ethiopia, pp. 10-60.

23. Karp, A., Kresovich, S., Baht, K.V., Ayad, W.G. and Hodgkin, T. (1997). Molecular tools in plant genetic resources conservation: a guide to the technologies. IPGRI Technical Bulletin No. 2.

24. Kearsey, M.J. and Pooni, H.S. (1996). The Genetical Analysis of Quantitative Traits. Chapman and Hall, London. Weinhein, New York, 381 pp.

25. Lin, M.S. and Nelson, R.L. (1988). Relationship between plant height and flowering date in determinate Soya bean. Crop Sci. 28:27-30.

26. Melaku Worede (1988). Diversity and the genetic resource base. Ethiopian J. of Agri. Sci. 10:39-52.

27. Monti, L.M. (1992). The Use of Wild Species in Crop Improvement. In: International Institute of Tropical Agriculture (IITA). Biotechnology: Enhancing Research on Tropical Crops in Africa, pp. 55-62, (Thotappilly, G., Monti, L.M., Raj, D.R.M. and Moore, A.W., eds). Ebenezer Baylis and Son Ltd., United Kingdom.

28. Mulatu Geleta (2001). Ethnobotanical study of edible oil crops as a companion of Sorghum bicolor L. Moench and biochemical genetic analysis of in situ and ex situ conserved Guizotia abyssinica Cass. germplasm from North Shewa and South
Wello. MSc Thesis presented to the School of Graduate Studies, Addis Ababa University, Ethiopia, 149 pp.

29. Seegeler, C.J.P. (1983). Oil Plants in Ethiopia: Their Taxonomy and Agricultural Significance. Centre for Agricultural Publishing and Documentation, Wageningen, the Netherlands, 368 pp.

30. Shelemew W/Mariam (1985). Influence of seeding rates on yield, yield components and oil contents of six linseed (Linum usistatissimum L.) varieties. MSc Thesis presented to the School of Graduate Studies, Addis Ababa Agricultural University, Ethiopia, 75 pp.

31. SPSS (1999). sPSS for Windows: SPSS Base System Users Guide Version 10.0. Computer programme, Chicago, $\mathbb{L}$.

32. Toit, S.H.C., Steyn, A.G.W., and Stumpf, R.H. (1986). Graphical Exploratory Data Analysis. SpringlerVerlag, New York, 314 pp.

33. Vavilov, N.I. (1951). The Origin, Variation, Immunity and Breeding of Cultivated Plants, Vol. 13. The Ronald Press Company, New York, pp. 20-43.

34. Westphal, E. (1975). Agricultural System in Ethiopia: Centre of Agricultural Publishing and Documentation. The College of Agriculture, Haile Sellassie I University, Ethiopia, and Agricultural University, Wageningen, the Netherland- Agricultural Research Report 826, $278 \mathrm{pp}$.

35. Wuletaw Tadesse (1999). Morphological and biochemical diversity of grasspea (Lathyrus satious L.) in Ethiopia. MSc Thesis presented to the School of Graduate Studies, Addis Ababa University, Ethiopia, 108 pp.

36. Yemane Tsehaye and Fassil Kebebew (2002). Morphological Diversity and Geographic Distribution of Adaptive Traits in Finger Millet (Eleusine coracana L. Gaertn. subsp. coracana [Poeceae]) Populations from Ethiopia. Ethiop. J. Biol. Sci. 1:37-62. 